\title{
Towards a theory of parental support: Development of English First Additional Language for grade 4 learners
}

\begin{tabular}{|c|c|}
\hline $\begin{array}{l}\text { Authors: } \\
\text { Aubrey T. Tseb } \\
\text { Vanessa Scher }\end{array}$ & $\mathrm{man}^{2}$ (D) \\
\hline $\begin{array}{l}\text { Affiliations: } \\
{ }^{1} \text { Department } \\
\text { Psychology, Fa } \\
\text { Education, Un } \\
\text { of Pretoria, Pr } \\
\text { South Africa }\end{array}$ & $\begin{array}{l}\text { f Educational } \\
\text { culty of } \\
\text { iversity } \\
\text { etoria, }\end{array}$ \\
\hline $\begin{array}{l}{ }^{2} \text { Department } \\
\text { of Education, } \\
\text { Education, Un } \\
\text { South Africa, } \\
\text { South Africa }\end{array}$ & $\begin{array}{l}\text { Psychology } \\
\text { College of } \\
\text { iversity of } \\
\text { retoria, }\end{array}$ \\
\hline $\begin{array}{l}\text { Correspondin } \\
\text { Aubrey Tsebe, } \\
\text { tebogo.tsebe }\end{array}$ & $\begin{array}{l}\text { g author: } \\
\text { Dsmu.ac.za }\end{array}$ \\
\hline $\begin{array}{l}\text { Dates: } \\
\text { Received: } 14 \mathrm{~J} \\
\text { Accepted: } 03 \text { } \\
\text { Published: } 26\end{array}$ & $\begin{array}{l}\text { uly } 2019 \\
\text { Mec. } 2019 \\
\text { Mar. } 2020\end{array}$ \\
\hline $\begin{array}{l}\text { How to cite th } \\
\text { Tsebe, A.T. \& S } \\
\text { 2020, 'Toward } \\
\text { parental supp } \\
\text { Development } \\
\text { First Additiona } \\
\text { for grade } 4 \text { lea } \\
\text { Literator } 41(1) \\
\text { https://doi.org } \\
\text { v41i1.1642 }\end{array}$ & $\begin{array}{l}\text { is article: } \\
\text { cherman, V., } \\
\text { s a theory of } \\
\text { ort: } \\
\text { of English } \\
\text { l Language } \\
\text { rners', } \\
\text {, a1642. } \\
\text { /10.4102/lit. }\end{array}$ \\
\hline $\begin{array}{l}\text { Copyright: } \\
\text { (C) 2020. The A } \\
\text { Licensee: AOS } \\
\text { is licensed unc } \\
\text { Creative Comn } \\
\text { Attribution Lic }\end{array}$ & $\begin{array}{l}\text { uthors. } \\
\text { IS. This work } \\
\text { ler the } \\
\text { nons } \\
\text { ense. }\end{array}$ \\
\hline Read online: & \\
\hline 口if: & $\begin{array}{l}\text { Scan this QR } \\
\text { code with your } \\
\text { smart phone or } \\
\text { mobile device } \\
\text { to read online. }\end{array}$ \\
\hline
\end{tabular}

This article sought to conceptualise guidelines that can assist parents in supporting learners' development of skills in English First Additional Language (EFAL). It argues that there is a need for a theory of parental support with regard to the development of EFAL of learners. English is both a First Additional Language (FAL) and the Language of Learning and Teaching (LoLT) in most schools in South Africa. English is a home language to less than ten percent of South Africans. Therefore, for learners who do not have English as their mother tongue, there is an urgent need for language support. This article demonstrates that parents, as key stakeholders in development of EFAL at home, need guidance on how to provide support. Eight $(n=8)$ parents were selected conveniently to form part of the focus group discussions and to gain understanding of their experiences with regard to supporting the development of EFAL. The results revealed that parental support is a complex process that requires one to consider the interface of systems around the parent and the child. Consequently, the theory of parental support describes how, through the interface of these principles, parents can support second language development. The results of this study have pragmatic and policy implications for parental support with regard to the development of EFAL.

Keywords: English; learners; parents; theory of parental support; language development.

\section{Introduction}

This article contributes to knowledge pertaining to the role of parental support in the development of language skills. Ultimately, this knowledge assists in developing guidelines for working towards a theory of parental support through which parents can support learners' development skills for English First Additional Language (EFAL) or a second language. The factors that influence poor learner performance are complex and may include poor language development, lack of educational resources and lack of teacher and parental support (Dhurumraj 2013; Evans et al. 2010). However, researchers concur that parental support with regard to language development could make a significant contribution to the academic outcomes of South African learners (Daniels 2017; Evans et al. 2010; Howie et al. 2017; Mmotlane, Winnaar \& Wa Kivilu 2009). First Additional Language (FAL) competency is vital as learners switch to English as the Language of Learning and Teaching (LoLT) and that affects the overall academic achievement (Department of Education 2003; Prinsloo, Rogers \& Harvey 2018). These two issues, language and parental support, are the main foci of this article.

The focus of the current research also finds relevance in scholarship given the attention that the topic of parental support, with regard to second language development, has received worldwide (see studies by Deborah, Gilliam \& Lisa 2013; Georgis, Donna Mae Ford \& Ali 2014; Wessels 2014). For example, Chinese-based scholarly research has shown that most parents are very active in supporting their children in learning EFAL, as they consider it fundamental to their children's future (Lau, Li \& Rao 2011; Wei 2011, 2014). There is a consensus in international literature about the positive effect of parental support on the academic achievement of children, which includes the development of second language proficiency (Boonk et al. 2018; Castillo \& Gàmez 2013; Castro et al. 2015; Daniels 2017; Enemuo \& Obidike 2013; Evans \& Cleghorn 2014; Gilleece 2015; Jeynes 2007, 2012; Liu 2013; Wang 2014). Therefore, this article finds relevance within the current body of literature in providing guidelines for working towards a theory of parental support that is expected to support developing second language proficiency among South African learners. Therefore, the results of this research have the potential to contribute to knowledge in the field of parental support with regard to second language development.

This article is guided by the main research question, 'what guidelines can be provided for working towards a theory of parental support?' To answer this research question, we offer a broad insight 
into these two above-mentioned issues in the further sections. We, firstly, review the literature on EFAL and parental support. A conceptual framework that underpinned the current research follows the 'Literature review' section and an overview of the methodological process is provided. The results and discussions of the current research are provided before the concluding section.

\section{Literature review}

The South African education system is affected by a myriad of unique challenges as compared to education systems in other nations around the globe (Howie et al. 2008, 2012, 2017). Ramrathan (2017:23) compared the results of grade 6 learners across four countries in Africa and concluded that the 'South African schooling system is failing its citizens', revealing that the educational system of South Africa is not getting better. Ramrathan's conclusions (2017) do not come as a surprise given what Bloch (2009:17) stated over a decade ago that, 'there is no shortage of evidence showing how badly the South African education system is performing.' Glaring evidence of the poor performance in the education system is provided by the recent report of performance of learners in South Africa compared to their peers around the world. The latest results from the Progress in International Reading Literacy Study (PIRLS), where learners are tested in their 'home' languages, show that South African learners performed below all 50 participating countries (Howie et al. 2017). This poor performance is corroborated by previous large-scale studies such as those conducted by the Southern and Eastern African Consortium for Monitoring Educational Quality (SACMEQ 2011), Progress International Reading Literacy Study (PIRLS) 2006 (Howie et al. 2008), Progress International Reading Literacy Study (PIRLS) 2011 (Howie et al. 2012) and the annual national assessments (ANA) (Department of Basic Education 2012a) all of which reveal that South African learners are performing below the required level.

Looking at the challenges faced by the South African education system, language is arguably among the biggest concerns (Nel 2011; Stein 2017). For example, studies focusing on school resources (Munje \& Maarman 2017) and key subjects such as mathematics (Mji \& Makgato 2006; Stott 2015) and physical science (Mji \& Makgato 2006; Prinsloo et al. 2018) have shown that challenges with language in education and lack of resources cause poor performance among learners. The language in education problem could be associated with the fact that, English as the LoLT in the majority of schools, is a home language to only $8.1 \%$ of South Africans (Statistics South Africa, 2018). Results from PIRLS 2006 reported that South African grade 4 learners obtained a score of 353 , and grade 5 learners obtained a score of 302 . Both scores were significantly below the international average of 500 . When compared to other countries, South Africa performed poorly and this highlights the need for attention (Howie et al. 2008, 2017).

In 2011, a new PIRLS approach, which differed from that used previously in other countries (Howie et al. 2017), was adopted for testing South African grade 4 literacy. This new assessment tool, pre-PIRLS, was a relatively easier assessment compared to the standard PIRLS tests used for the grade 4 learners in other countries. The results from this assessment, however, showed that the overall performance by South African learners was 323, which is still below the overall international mean of 500 (Howie et al. 2017). Comparing the 2016 and 2011 grade 4 results, it can be noted that the difference in scores is not statistically significant (Howie et al. 2017). Although there were some improvements in the performance in five African languages (i.e. isiNdebele, Sepedi, Sesotho, Tshivenda and Xitsonga) in grade 4, performance of South African learners still begs serious attention (Howie et al. 2017). The overall performance of both grades 4 and 5, where learners were tested in English or Afrikaans, indicates that the trends of poor performance still persist. The under-achievement of South African learners in language seems to be a complex problem, and there are no obvious solutions. As such, more time is needed for research and interventions before solutions can be realised.

Furthermore, parents as key figures in the lives of their children cannot be excluded in the effort to try to address this problem. The Department of Basic Education (DBE) has attempted to get parents involved in their children's education through the introduction of the school governing body (SGB) (South African School Act 1996). The main stakeholders in the SGB are the parents and their responsibility is governance of the school. One of the key responsibilities of the SGB is related to the language policy of the school, specifically on deciding the LoLT (DBE 2014; South African Schools Act 1996). This implies that parents can decide through the SGB on the LoLT. Therefore, it is on the premises of this power that is held by the parents that one could logically expect them to be active in supporting the language development of the learners. On the contrary, Mmotlane et al. (2009:528) stated that 'low parental participation in activities of the school has been detected in South African black schools in recent years.' The lack of parental involvement is a matter of concern in the current study given the critical role of parents, as indicated above.

Thus, although the SGB serves as a platform for involvement of parents, it must also be noted that not all parents can take part in the SGB because of its size (Department of Basic Education 2015) and the lack of effective management of SGB operations that could afford equal access opportunities to all parents (Mncube, Harber \& Du Plessis 2011). Reasons for lack of involvement are, however, not limited to the state of the SGB or its operations. There are also other factors, for example, some parents want to get involved, but they do not know how to (Mbokodi \& Singh 2011; Mncube et al. 2011), a view consistent with studies conducted in the United Kingdom (See Okeke 2014; Willemse et al. 2018) and another conducted in Nigeria (Enemuo \& Obidike 2013). In other instances, age seems to play a role, with young parents (35-49 years) showing more interest in involvement than older parents (Mmotlane, Winnaar \& Wa Kivilu 2009). Some parents do not get involved because of insecurity which arises from their low levels of education 
(Mncube 2009) and lack of proficiency in the English language which is used by the school as FAL (Mbokodi \& Singh 2011). Other parents do not view involvement in their children's education as their role, but rather, they restrict that role to the teachers. For example, a research study conducted in the Eastern Cape province of South Africa showed that parents associate their involvement with only home-based activities such as providing support for homework (Page 2016). The above factors are just a sample of issues reflected in the research conducted in different provinces in South Africa, suggesting that there are real problems arising from lack of parental involvement in the language education of their children.

It is therefore crucial to address this problem of lack of parental involvement to advance the South African education system. In addressing this problem, the relationship between parental involvement and second language support is relevant to this article. Therefore, it is in the problematic context of limited language proficiency and lack of parental involvement that this article finds significance.

\section{Conceptual framework: Dynamic systems theory}

In this article, we adopted the Dynamic Systems Theory (DST) as a conceptual framework based on its non-linear approach to studying a phenomenon that changes over time (De Bot \& Larsen-Freeman 2011; De Bot et al. 2013). Parental support and second language development are such phenomena, in that they undergo a dynamic process. In the context of the current research, second language is the main dynamic system of focus, and both language development (or language learning) and parental support are the dynamic processes. Therefore, the dynamic and systemic perspective of DST fits best for the current research, which focuses on both the second language system and the two aforementioned dynamic processes.

With regard to parental support in the context of education, there are various frameworks that one can choose from, especially the widely used models such as Epstein (Epstein 2010) and Hoover-Dempsey (Tekin 2011). Although both these models provide an understanding of parental support, they are not developed to provide support specifically for second language development. That is one of the distinctions that sets DST apart from other theories, in that not only does it provide tools to understand systems important for the child, it was also specifically developed as a comprehensive theory of second language development (De Bot, Lowie \& Verspoor 2007; De Bot et al. 2013). It is, therefore, on the basis of the above-mentioned factor, among other key characteristics such as open systems, sensitive dependence on initial conditions, nested system and subsystems or nestedness, non-linear development, variability (both in and among individuals), self-organisation and feedback loop, that we have chosen DST as a guiding framework for this article.

\section{Research methodology Methodology}

The original study made use of an explanatory sequential design of mixed methods research, which had two phases. The first phase focused on the secondary quantitative data from PIRLS, while the second phase focused on the qualitative data. The explanatory sequential design is characterised by the collection of quantitative data first, followed by qualitative data. The explanatory sequential design, also referred to as 'a two-phased model' (Creswell 2012:542), was well fitted for the original research which had two phases: the quantitative and qualitative data collection and analysis processes. The first phase was used to form a benchmark for understanding the significance of the parental involvement problem and language development in South African learners. Therefore, the results from quantitative data were explored further through the qualitative approach.

\section{Ethical consent and sampling}

Ethical approval to conduct the study was obtained from the University of Pretoria (Ethical Clearance Number: EP 13/11/01). Following the approval, a faith based organisation in Pretoria was identified as the data collection site based on its capacity to members from diverse backgrounds and major communities around Pretoria. Following an approval by the organisation, members were informed and those interested in participating in the current study submitted their names and contact details. A convenient sample of eight parents formed part of the research based on their accessibility, availability and willingness to be part of the current research (Etikan, Musa \& Alkassim 2016). The participants were parents of learners of English as the FAL, and Table 1 shows the background information of the participants.

\begin{tabular}{|c|c|c|c|c|c|c|}
\hline Number & Marital status & Gender & Employment status & Highest qualification & Parenting role & Child's grade \\
\hline 1 & Single & $\mathrm{F}$ & Unemployed & Degree & Single parent & Grade 3 \\
\hline 2 & Single & $\mathrm{F}$ & Unemployed & Matric & Guardian & Grade 4 \\
\hline 3 & Single & $\mathrm{F}$ & Employed & Diploma & Guardian & Grade 4 \\
\hline 4 & Married & $\mathrm{F}$ & Employed & Matric & Both parents & Grade 2 \\
\hline 5 & Single & $\mathrm{F}$ & Employed & Honours degree & Both parents & Grade 3 \\
\hline 6 & Divorced & M & Employed & Honours degree & Single parent & Grade 3 \\
\hline 7 & Married & $\mathrm{F}$ & Employed & Diploma & Both parents & Grade 4 \\
\hline 8 & Divorced & $\mathrm{F}$ & Employed & Degree & Single parent & Grade 4 \\
\hline
\end{tabular}

F, female; $M$, male. 


\section{Data collection and analysis}

A focus group interview was used for data collection. Focus group interviews were chosen based on the strength they had to provide in-depth data that are not attainable from individual interviews (Nieuwenhuis 2007). The focus group discussions were conducted on two occasions over a period of 2 weeks. During the focus group interview discussions, care and judgement were prominent by using an audio recorder to ensure that data were not lost in the process (Stewart \& Shamdasani 2015). Secondly, the data recorded were sent to a professional transcriber who documented all the focus group discussions. The transcripts were used to conduct a thematic analysis of the results (Maguire \& Delahunt 2017; Vaismoradi et al. 2016).

Thematic analysis followed an inductive process, where data content from participants was analysed to form general themes (Teddlie \& Tashakkori 2009). The themes were identified by following the four-phase theme development process set by Vaismoradi et al. (2016:102-107), namely, initialisation, construction, rectification and finalisation. The initialisation phase includes reading through the transcripts for coding purposes, which helps in reducing the raw data into meaningful units (Maguire \& Delahunt 2017). During the coding process, titles were given to each transcript; code ' $1 \mathrm{M}$ ' referring to the first meeting and code ' $2 \mathrm{M}$ ' referring to the second meeting. Each statement were also numbered, per meeting. Therefore, a quote with reference ' $1 \mathrm{M} 2$ ' indicates that the extract can be found on the document entitled First Meeting, line number 2. This example indicates how all extracts should be understood as used in the 'Results' section. The construction phase focused on the identification, comparison and description of identified themes. The rectification phase took a paradoxical format of immersing and distancing oneself in the identified data for the purpose of increasing the critical approach in analysing the presented data. The finalisation phase includes portrayal of the identified themes through a storyline, which provides a coherent picture of the results of the current study. The themes identified through the above-mentioned four-phase process were then used for data analysis.

\section{Quality criteria}

Quality assurance of the current research was ensured through the process of trustworthiness and transferability. The qualitative term, trustworthiness, is achieved by engaging in multiple methods of data collection (Nieuwenhuis 2007). The use of an experienced transcriber ensured that the views and experiences of the participants are documented correctly, which helped to increase the trustworthiness of the results (Patten \& Newhart 2018). Therefore, member-checking the transcripts of the current study with participants helped to confirm whether the conclusions drawn from the study were accurate in reflecting the views of the participants. With qualitative data, transferability looks at the how the results of the current study can be applied in other contexts different from the one of the current study (Wium \& Louw 2018). The limited number of participants for the qualitative study suggests that the results from this phase can only be transferred to a population similar to the population of this study.

\section{Results}

According to Stewart and Shamdasani (2015), presentation of focus group data is not a simple process; it requires care and judgement. In the current research, care and judgement were ensured by following the four-phase guidelines suggested by Vaismoradi et al. (2016:102-107), as described in the above section. Both the frequency and contents of the statements of the current research were considered on how they assist in answering the main research questions, 'what guidelines can be provided for working towards a theory of parental support?' The main question was supported by the following sub-questions: (1) 'what challenges are faced by the parents of EFAL learners with regard to supporting language development?' (2) 'what are the characteristics of guidelines for working towards a theory of parental support?' Below, I describe how our research answered these questions, starting with the first sub-question. It is, therefore, based on the above backdrop that six themes emerged from the qualitative data analysis: (1) alternative parenting; (2) parent-child activities, (3) technology and surfing the net support, (4) parental challenges, (5) language usage and (6) quality of education.

\section{Alternative support}

Alternative parenting is considered as a form of parenting that includes any person playing the role of a parent other than the biological parent of the learner (South African Schools Act 1996). The following extracts relate to situations where the role of alternative parenting is seen in afterschool care centres, with family relatives, extra classes and tutors:

'Okay what I do is that, I involve my kids for after care (Grade 4), which is a school after care. I opted for that one because of the curriculum; they know the system and everything. So, they are assisted with homework. They have homework for reading and after reading what they do are the English activities. Every day they are given activities to complete.' (Zen, 1M2 [authors' own emphasis])

'My one (referring to the child) is in Grade 3. What I do every day, I have an aunt at home and she is living at home so I ask her to assist my child when doing homework. (Referring to activities while the mother still at work).' (Tsebe, 1M5 [authors' own emphasis])

'That's why even at school they introduced extra classes... (Referring to the view raised during discussion that parents do not have time to assist their children at home).' (Zen, 2M216 [authors' own emphasis])

From the above extracts, alternative parenting support ranges from providing support for homework to helping language development through reading activities, key tasks 
that a child has to do after school. For example, in the literature review, it was clarified how reading, especially in early childhood, helps in language development (Du Plessis 2012; McCabe 2011). Alternative support reduces the direct involvement of parents in supporting their children in the trajectory development of EFAL. It seems that with many parents working full-time, alternative parenting support reduces the time constraints that parents might have in supporting their children through completing homeworkrelated tasks and reading, although it seems that the parents do confirm that the schoolwork is completed well by signing the homework diary.

\section{Parent-child activities}

Parent-child activities refer to the educational activities that parents engage in with their children for educational support, and specifically language development. It was indicated that identification of the activities undertaken by the parents with their children should be seen as a form of learner support and an indication of parental involvement. These activities include going through the work done at the aftercare support and reading:

'And then when they get home what I do is I go through what they did at after care. And then sometimes you will find that there are mistakes, so I will go through the mistakes with them and rectify where they went wrong, and they will also read to me as well and then I will sign next to the teacher's signature to say that I went through the reading as well.' (Ester, 1M2 [authors' own emphasis])

'So, I correct her, I don't ask aunt to correct it and I don't ask aunt to do it with... So, she must do it alone and then when I come back, I will mark and check where she went wrong and then I will call her and say this is wrong, do it.' (Zen, 1M5 [authors' own emphasis])

Another form of parental involvement is reading to the child, and/or with the child. In the extracts below, the parents make some effort to read with the children. We refer to this as an effort because it does not seem to work out as much as the parents would have preferred. It is an effort because the parents indicated that often the children do not want to read:

'He will only read when I'm sitting like maybe with notes and stuff, or if I'm taking my books to read, is when he will show interest and read and go through.' (Moekie, 1M29 [authors' own emphasis])

'But what I have seen is that now she is starting to read because she sees me reading, I had to find out what she loves in the reading.' (Moekie, 1M17 [authors' own emphasis])

What motivates children to read is when they see their parents reading, and often this happens when parents engage in their personal studies or reading any other material. In the absence of parents' studies, it does not appear as if parents make conscious decisions to get books to read as a way of modelling reading for their children. It seems to happen as an intervention measure used when needed to get the children to read or to listen to their reading homework. This suggests that parents lack a culture of reading for leisure to model reading for their children. This could also be related to the unwillingness of children to read, as reading might not be the norm in their homes and a culture of reading has not been developed in the home.

\section{Technology and surfing the net support}

Technology and surfing the net support emerged very strongly and included accessing educational material on the Internet, Google search, WhatsApp and educational programmes on television. As reported by Howie et al. (2008:36):

As part of everyday experiences outside of school, learners may be exposed to a wide variety of texts ranging from magazines, books, newspapers or text in electronic format as found on television subscripts and the Internet.

In the extract below, the parent has used the Internet to find reading information, downloaded it and printed it for the child to read. Access to books may be difficult and expensive, but this is one way in which the parent has become involved in creating literacy activities to support language development:

'But then what I've done from my side, I've printed these Bible stories from the internet and made a file for him.' (Moekie, 1M29 [authors' own emphasis])

In the next extract, one parent has used the Internet to source worksheets for the child as extension work, which shows the interest that the parent has in the child's language and academic development:

'The worksheet, master one, the one that I said I download every day, it has problems, and memorandum....' (Tseba, 1M176 [authors' own emphasis])

The parents indicated the easy availability of providing reading enhancement material solutions to support children through the Internet and the WhatsApp social media platform. The use of social media seems to work well as a supporting tool in the language development of the child. As society moves into the electronic age, more and more available apps seem to rule lives. Social media platforms, such as WhatsApp, have provided a link between school and parents and parents themselves. It is clear from the results that participants of the current research expressed strong views about the role of technology and surfing the net in providing parental support.

\section{Parents' challenges}

Parents' challenges refer to trials faced by parents which hinder parental involvement in their children's education (Slain 2019). Although the challenges differ from parent to parent, there are general challenges that they face $\left(\mathrm{O}^{\prime}\right.$ Donoghue 2014). For example, some parents indicated that their children often refuse to read when requested to do so. The reason for this refusal was not explored as it was outside the purpose of the current study, although one parent suggested that this might be because of the stubbornness of the child.

'My challenge is reading. She doesn't want to read ...' (Jess, 1M5 [authors' own emphasis]) 
To some parents, time is an issue as indicated in the extract below:

'But where is the time? I don't think the time is not enough..., we come back at $4,7 / 8$ is bed time, where do we have this time to (read with the child).' (Superman, 2M210 [authors' own emphasis])

Therefore, in this article, four sub-themes of parental support, parent-child relationship, time, helplessness and understanding of the child's curriculum, sum the challenges encountered by parents in supporting their children in the development of language proficiency. The challenges that parents face with regard to relationships with their children revolve around the home activities. To overcome these challenges, a parent support theory, taking into consideration the curriculum and the reasons that can hinder children from reading, must be developed.

\section{Language usage}

Language usage in this article refers to the language used by parents in providing parental support. It is through the medium of language reflected through the attitudes of parents towards reading and their participation in activities aimed at language use and development that they can either promote or hinder language usage. This theme reflects on how parents and their children use language and the views they have about language. The language usage theme includes the following sub-themes: mother tongue, language levels, language used during home activities, English as an international language and reading.

With regard to the mother tongue versus EFAL, parents spoke on the importance of the use of English in reading. Although parents indicated that they value their mother tongue, they viewed it as important only for communication reasons and not for academic purposes:

'Our mother tongue is not necessary for them to be fluent in, he can talk the mother tongue we can understand ...' (Superman, 2M122 [authors' own emphasis])

It was, however, noted that parents were unsure about the language levels, that is, which between the home language and English is their first language or FAL. The extract below reveals this confusion:

'My understanding, as long as the language is not your mother tongue, it automatically means she [the child] is doing it as a second language.' (Superman, 2M7 [authors' own emphasis])

The parents cited the limitations of mother tongue versus the international value of English as the main reason for preferring English. It was on this basis that parents opted for English development instead of mother tongue:

'Everything is in English, I'm telling you ....' (Zen, 2M72 [authors' own emphasis])

In fact, the mother tongue was viewed as a hindrance to the development of English and limiting the child's career. The aforementioned view is supportive of the rationale of the current research that aims at developing guidelines for working towards a theory of parental support. It is anticipated that such a theory will assist in promoting the importance of the mother tongue (or the main language used in the home) to serve as a springboard for the development of EFAL. Such knowledge will add value to the current debates in South Africa about general language usage and, particularly, the value of promoting previously marginalised languages.

\section{Quality of education}

Quality of education refers to that standard of education and services that the school offers. The extract below represents the views of the parents about what is offered to their children at public schools in the township schools compared to the schools in towns:

'It's just that now, the fact that you take your child there, it means that you're not going to have much (with regard to school services).' (Jess, 2M60 [authors' own emphasis])

Parents were critical of township schools as they felt that they did not offer quality education, comprising an inclusive broad curriculum incorporating extra-curricular activities, which is vital in equipping their children for their place in today's changing society.

'[...] if the location (township) schools is giving as much extra murals and their advancement, we would have no problem. We would take our kids there but because now you can see that the world has changed, if you are going to take your child in there (township schools), they are not going to learn how to swim. They are not going to learn a lot of things. So, you will be setting them up for a bit of a failure.' (Zen, 2M53 [authors' own emphasis])

The quality of education was discussed in the literature review as one of the main reasons for the poor performance of the learners (DBE 2012b; Howie et al. 2008). Many factors influence quality in schools and factors such as size of class, curriculum coverage, poor resources and the competence of the teacher all have an effect on parents' decisions about where to enrol their children. Therefore, these findings suggest that the challenge of quality of education should be considered attentively to understand its impact in influencing the decisions of the parents regarding school choice.

\section{Discussion}

According to Stewart and Shamdasani (2015), the success of a focus group can be measured by the consistency of the results to the objectives of the research question. Similarly, the focus group was intended to answer the research questions of the current research (see the 'Results' section). The parents' challenges theme aimed to answer the first subquestion. The parents' challenges shed some light on what specifically hinders parental involvement (Akinsola 2011; Ibukunolu 2013).

The main challenge that the parents emphasised was the difficulty in trying to get their children to read or do homework activities, which are the seminal activities they do with children. This challenge is characterised by DST's 
concept of sensitive dependence on initial conditions or the butterfly effect. A concept attributed to Edward Lorenz (Briggs \& Peat 1999), which is expressed in his question, 'does the flap of a butterfly's wings in Brazil set off tornado in Texas?' It is an analogy used to describe the ability of small changes (analogous to the flap of the wings), making an impact somewhere very far (analogous to the distance between Brazil and Texas). Therefore, the parents involved in the current research focused on encouraging their children to read (flap of butterfly), although they did not know how to guide them through techniques such as shared reading. As such, most parents put the blame on their inability to understand the curriculum as the cause of their children's inability to read. The aforementioned view is in contrast to the butterfly effect of DST. The trajectory of children's language development, including their ability to learn, should be viewed within the nested systems that play a role in this process. In other words, the child's willingness to read (language learner system), parental skills (family system) and availability of reading materials (family system) are among the important initial conditions that are important for one to understand the trajectory of language development. For example, a longitudinal study over 27 nations (including South Africa) revealed that a scholarly culture, which includes parents making more books available at home and modelling this culture by engaging with the books, enhances the children's educational achievement (Evans et al. 2010). The study further states that the effects are 'strong among the underclass in a society designed to maintain group privileges such as South African black people under apartheid' (Evans et al. 2010:17), which typifies the parents in this study. Therefore, the challenge of not being able to get children to read is an important fact given the role that shared reading has on the child's academic achievement.

The parents can, therefore, provide this support either personally or through the assistance of alternative support options, which have been shown to have the potential to close the gap. The use of alternative support could address the issue of limited time and feelings of helplessness which are triggered in parents trying to get their children to read. The alternative support can also mediate the lack of understanding of the curriculum. However, this challenge is not unique in that Dampier (2014) noted that lack of clarity by the Department of Education (DOE) is evident in the curriculum. Therefore, the lack of clarity could be viewed as an indication of a gap in policy development about what the school expects from parents. Although there are some documents that are aimed at parental support, with the Practical Guidelines: How parents can Contribute Meaningfully to the Success of their Children in Schools (DBE 2016), being close to what is recommended, such documents fall short of supporting parents fully. Apart from the fact that they are not policies, they also lack the practical comprehensive guidelines, which ought to take into consideration the socioeconomic and systemic challenges of parents. It would, therefore, be beneficial to develop parental support guidelines that take into consideration the aforementioned challenges faced by South African parents.
The six characteristics of DST help to conceptualize of guidelines which can be used towards the development of the theory of parental support. From a dynamic systems perspective, these principles are not viewed independently, but rather as having a relationship to each other. The relationship between the systems indicates the nestedness principle of DST. Both nestedness and openness are DST's principles related to theme 1 (alternative parenting). The openness principle implies that there cannot be control on the number of, or the type of, inputs that the system will receive from the environment. Nestedness refers to the fact that all parts within and outside the systems are connected (De Bot \& Larsen-Freeman 2011). For example, nestedness might be shown by some parents' (family system) reliance on alternative parenting (theme 1) support subsystems, such as tutoring and after-school day care to support their children (school or social systems) (Hofmann \& Wan 2013; Phillips 2011). The aforementioned subsystems are able to have a mutual effect on the parental system because of its openness as all the systems and their subsystems possess the same properties. Therefore, because of this openness, the system self-organises itself to maintain order.

Self-organisation is another DST principle that refers to the emergence of order of patterns as the system interacts with its surrounding environment. It is related to the feedback loop principle of DST. The feedback loop refers to the process through which the dynamic system governs itself (Queen's University 2018). For example, the aforementioned need for alternative parenting (school or social systems) seems to be associated with the parents' view that they do not know the school (school system) curriculum well (understanding child's curriculum is a sub-theme of theme 4), and they also do not have enough time (sub-theme of theme 4) to assist their children. This implies that through the feedback between parents and school, the system ends up providing its own support from other support structures within it (e.g. support from a family member) or a larger social system (tutorials or after-school care) to allow EFAL support to learners in the midst of challenging factors (such as socioeconomic factors) (Hall \& Posel 2012; Statistics South Africa 2011). This is further augmented by their admitted lack of information about what is expected of them, resulting in feelings of helplessness (sub-theme of theme 4).

In tandem, the work done by alternative parenting support services can either be of benefit to the parents or add more work. As Prinsloo (2008) states, extra classes are beneficial when conducted by well-trained teachers and tutors. Because parents indicated that they tend to fix errors made by the after-school care workers (see theme 2), it seems that those who offered alternative parenting services to the parents in the current study did not provide sufficiently satisfactory services. In addition, the shortage of tutors (part of theme 1) offering assistance in the mother tongue (sub-theme of theme 5) was also raised as a concerning factor; hence, the parents opted for services in English. Although this decision provides exposure to English, such a decision seems to hamper second 
language development as parents indicated that their children's proficiency in their mother tongue was not well developed. The literature reviewed (Bouwer 2004; DBE 2003; Nel 2011) shows that children who have not acquired language skills in their mother tongue invariably have difficulty in second language development. Therefore, although alternative parenting seems to have the potential to alleviate the burden of work upon the parents, within the framework of parental support, it should be viewed in relation to its interconnected themes, such as the challenges of parents (theme 4), use of mother tongue (theme 5) and the quality of education offered (theme 6).

\section{The interrelationship between the various themes}

It seems as if the parents in the current study indicated that they prefer focusing on monitoring what has already been done by the school, after-school care centres or tutors because of time constraints. The time constraints do not only determine how parents engage in activities (theme 2) with the child, but their decision to seek alternative parenting support (theme 1). Reciprocally, depending on the quality of work done by after-school care workers, this could affect the amount of time parents have to spend checking their children's work.

The decision by parents to focus on work done by the afterschool care centres is motivated by the fact that most of the parents who participated in the current study indicated that they feel uninformed about what the school expects from them (understanding child's curriculum sub-theme of theme 4). It was on this basis that technological (theme 3) advancement, such as social media platforms like WhatsApp, emerged as a supporting tool. A trend consistent with the literature is that technology could be used to mediate second language learning (Kern 2014). Thus, parents indicated the use of the school's WhatsApp group to update and provide easy access to information about schoolwork. Therefore, in the current research, technological interventions and Internet (theme 3) access served in bridging the gap between the teacher (school) and the parent.

These results suggest that a proper investment in the net surfing and technological approaches to education that focus on parents have the potential to benefit parental support. This view is consistent with emerging trends from the literature about technological and social media usage within education (Donnerstein 2013; Symington \& Dunn-Coetzee 2015). Through technology, parents can also be active in holding the school or after-school care centre accountable to deliver on their promises of helping their children. For example, applications such as 'Team viewer' and 'Facebook live' can be explored to provide a platform for parents' access to what is happening in their children's learning environment. The platforms could also help teachers who serve as support tools in providing proof of what was covered in class. Therefore, technology and the Internet as mediating tools for second language development (Kern 2014) can also play a crucial role, together with the interacting themes, as supporting tools for second language development in the theory of parental support. Reciprocally, the development of second language could be enhanced through the use of Internet and certain technological devices.

In summary, the discussion about the guidelines towards the development of a theory of parental support and interacting factors reveals that second language development is a complex process. Thus willingness to learn, similar social background and attending the same school is what the authors refer to as similar initial conditions; this cannot predict the outcome of their level of language development in the future. Each child, based on the complexity of both the internal and external factors, will follow a different trajectory towards language development. In addition, it must be acknowledged that language problems are not only experienced at the mother-child level; rather, they are a global problem that must be addressed within a larger social system. On a practical level, this suggests that if key figures in government and the DOE do not use the mother tongue in their official communication (Banda 2000), parents and children might not be motivated to do so. Reciprocally, that could also affect the efforts of the department when trying to improve mother tongue proficiency and how that could mediate development of the FAL (DBE 2013). Therefore, a theory of parental support, presented by the current research, advocates the importance of mother tongue development and the use of EFAL. Without such an approach, knowledge about second language development, as established in the literature, is likely to remain the privileged domain of academics but inaccessible to parents who also need it (Banda 2000; Cummins 2008, 2012).

\section{Conclusion}

The main purpose of the current research was to contribute to knowledge on parental support. Ultimately, this knowledge was aimed at formulating guidelines for working towards a theory of parental support with regard to second language development. The study has achieved its purpose in that it provided guidelines that can be used towards the development of a theory of parental support. The findings of the current research can be used by the DOE to develop a parental support policy document (e.g., an information booklet), which clearly states the department's expectations and provides clear guidelines on how parents can achieve the stipulated expectations taking into consideration their socioeconomic and systemic challenges. Further research is recommended, to explore the proposed guidelines and apply them in developing a theory of parental support as an intervention tool for parental support with regard to second language development. In the process of the current study, I have discovered that parents face various challenges that hinder their role of supporting their children. It is, therefore, my hope that, if these challenges are overcome, through the implementation of the guidelines and recommendations provided in the above sections, parents will be equipped to engage more in their children's education. 


\section{Acknowledgements Competing interests}

The authors have declared that no competing interest exists.

\section{Authors' contributions}

All authors equally contributed to this work.

\section{Funding information}

This research has been made possible through the financial support from the National Institute for the Humanities and Social Sciences, in collaboration with the South African Humanities Deans Association, for their financial assistance towards this research. It must, however, be noted that the opinions expressed and conclusions arrived at are those of the authors, and are not necessarily to be attributed to the National Institute for Humanities and Social Sciences (NIHSS) and the South African Humanities Deans' Association (SAHUDA).

\section{Data availability statement}

Data sharing is not applicable to this article as no new data were created or analysed in this study.

\section{Disclaimer}

The views and opinions expressed in this article are those of the authors and do not necessarily reflect the official policy or position of any affiliated agency of the authors.

\section{References}

Akinsola, E.S., 2011, 'Relationship between parenting style, family type, personality dispositions and academic achievement of young people in Nigeria, Life Centre for Psychological Studies and Services 19(2), 246-267. https://doi.org/10.4314/ifep. v19i2.69539

Banda, F., 2000, 'The dilemma of the mother tongue: Prospects for bilingual education in South Africa', Language, Culture and Curriculum 13(1), 51-66. https://doi. org/10.1080/07908310008666589

Bloch, G., 2009, The toxic mix: What's wrong with South Africa's schools and how to fix it, Tafelberg, Cape Town.

Boonk, L., Gijselaers, H.J.M., Ritzen, H. \& Brand-Gruwel, S., 2018, 'A review of the relationship between parental involvement indicators and academic
achievement', Education Research Review 24, 10-30. https://doi.org/10.1016/j. achievement', Educatior
edurev.2018.02.001

Bouwer, C., 2004, 'Reading and writing', in I. Elof \& L. Ebersohn (eds.), Keys to educational psychology, pp. 83-118, UCT Press, Cape Town.

Briggs, J. \& Peat, F.D., 1999, Seven life lessons of Chaos: Spiritual wisdom from the science of change, Harper Collins Publishers, New York.

Castillo, R. \& Gàmez, L.C.C., 2013, 'Assisting your child's learning in L2 is like teaching them to ride a bike: A study on parental involvement', Gist Education and Learning Research Journal 7, 54-73.

Castro, M., Exposito-Casas, E., Lopez-Martin, E., Lizasoain, L., Navarro-Asencio, E. \& Gaviria, J.L., 2015, 'Parental involvement on student academic achievement: A meta-analysis', Education Research Review 14, 33-46. https://doi.org/10.1016/j. edurev.2015.01.002

Creswell, J.W., 2012, Educational research: Planning, conducting and evaluating quantitative and qualitative research, Chapter 6, Pearson, Boston, MA.

Cummins, J., 2008, 'BICS and CALP: Empirical and theoretical status of the distinction', in B. Street \& N.H. Hornberger (eds.), Encyclopaedia of language and education, 2nd edn., Vol. 2: Literacy, pp. 77-83, Springer Science + Business, New York.

Cummins, J., 2012, Jim Cummins's second language learning and literacy web, viewed 12 June 2017, from http://iteachilearn.org/cummins/mother.htm.

Dampier, A.G., 2014, 'Second language acquisition and the national curriculum', Journal for Language Teaching 48(2), 37-51. https://doi.org/10.4314/jlt. v48i 2.2
Daniels, D., 2017, 'Initiating a different story about immigrant Somali parents' support of their primary school children's education', South African Journal of Childhood Education 7(1), 1-8. https://doi.org/10.4102/sajce.v7i1.461

De Bot, K. \& Larsen-Freeman, D., 2011, 'Researching second language development from a dynamic systems theory perspective', in M.H. Verspoor, K. De Bot \& W. Lowie (eds.), A dynamic approach to second language development: Methods and techniques, pp. 5-23, John Benjamin's Publishing Company, Amsterdam.

De Bot, K., Lowie, W. \& Verspoor, M., 2007, 'A dynamic systems theory approach to second language acquisition', Bilingualism: Language and Cognition 10(1), 7-21. $\mathrm{https}$ ://doi.org/10.1017/S1366728906002732

De Bot, K., Lowie, W., Thorne, S.L. \& Verspoor, M., 2013, 'Dynamic systems theory as a theory of second language development', in M. Mayo, M. Gutierrez-Mangado \& $\mathrm{M}$. Adrián (eds.), Contemporary approaches to second language acquisition, $\mathrm{pp}$. 199-220, John Benjamins, Amsterdam.

Deborah, R., Gilliam, F.G. \& Lisa, F., 2013, 'The family backpack project: Responding to dual language texts through family journals', Language Art 90(6), 402-416.

Department of Basic Education, 2012a, Report on the annual national assessments: 2012, Department of Basic Education, Pretoria.

Department of Basic Education, 2012b, Executive summary report on the delivery of textbooks in Limpopo: An update after the High Court ruling: 12th October 2012, Department of Basic Education, Pretoria.

Department of Basic Education, 2013, The incremental introduction of African languages in South African Schools: Draft Policy, Department of Basic Education, Pretoria.

Department of Basic Education, 2014, Guidelines relating to the elections of governing bodies of public schools, Department of Basic Education, Pretoria.

Department of Basic Education, 2015, Parental guideline booklet, viewed 13 June 2017, from http://www.gautengonline.gov.za/Publications $\% 20$ and $\% 20$ Reports/ Parental_Guidelines_Booklet.pdf.

Department of Basic Education, 2016, How you can play a role in the education of your children. Retrieved on 12 May 2016, from http://www.education.gov.za/ Informationfor/ParentsandGuardians.aspx.

Department of Education, 2003, Revised National Curriculum Statement Grade R-9 (Schools): Teacher's guide for the development of learning programmes, Department of Education, Pretoria.

Dhurumraj, T., 2013, 'Contributory factors to poor learner performance in Physical Sciences in KwaZulu-Natal Province with special reference to the schools in Pinetown District', Unpublished Master's dissertation, University of Southern Africa, Pretoria.

Donnerstein, E., 2013, 'Children, adolescents and the Internet: Are there risks online?', in K. Dill (ed.), The Oxford handbook of media psychology, pp. 373-381, Oxford University Press, New York.

Du Plessis, C., 2012, 'Facing up to literacy: Perceptions and performance in a test of academic literacy for postgraduate students', Journal for Language Teaching 46(2), 123-139. https://doi.org/10.4314/jlt.v46i2.8

Enemuo, J.O. \& Obidike, N.D., 2013, 'Assessment of parental involvement in children's literacy development', Journal of Emerging Trends in Educational Research and Policy Studies 4(5), 807-814.

Epstein, J.L., 2010, 'School, family and community partnerships: Caring for the children we share', Kappan 92(3), 81-96. (This article was originally published as "School/Family/ Community/Partnerships: Caring for the Children We Share" by Joyce L. Epstein. Phi Delta Kappan 76, no. 9 (May 1995): 701-712). https://doi. org/10.1177/003172171009200326

Etikan, I., Musa, S.A. \& Alkassim, R.S., 2016, 'Comparison of convenience sampling and purposive sampling', American Journal of Theoretical and Applied Statistics 5(1), 1-4. https://doi.org/10.11648/j.ajtas.20160501.11

Evans, M.D.R., Kelley, J., Sikora J. \& Treiman, D.J., 2010, 'Family scholarly culture and educational success books and schooling in 27 nations', Research in Socia Stratification and Mobility 28(2), 171-197. https://doi.org/10.1016/j.rssm. 2010.01.002

Evans, R. \& Cleghorn, A., 2014, 'Parental perceptions: A case study of school choice amidst language waves', South African Journal of Education 34(2), 1-19. https:// doi.org/10.15700/201412071203

Georgis, R., Donna Mae Ford, R.G. \& Ali, M, 2014, 'Creating inclusive parent engagement practices: Lessons learned from a school community collaborative supporting newcomer refugee families', Multicultural Education (Spring), 23-27.

Gilleece, L., 2015, 'Parental involvement and pupil reading achievement in Ireland: Findings from PIRLS 2011', International Journal of Educational Research 73, 23-36. https://doi.org/10.1016/j.ijer.2015.08.001

Hall, K. \& Posel, D., 2012, 'Inequalities in children's household contexts: Places, parental presence and migration', in K. Hall, I. Woolard, L. Lake \& C. Smith (eds.), South African Child Gauge 2012, pp. 43-47, UCT Press, Cape Town.

Hofmann, A. \& Wan, G., 2013, Determinates of urbanization, ADB Economic working paper series, Asian Development Bank, viewed 16 May 2017, from http:// anettjohn.com/docs/ewp-355.pdf.

Howie, S., Combrinck, C., Roux, K., Tshele, M., Mokoena, G. \& Palane, M.N., 2017, PIRLS Literacy 2016, Centre for Evaluation and Assessment, University of Pretoria, viewed 03 March 2018, from http://www.up.ac.za/media/shared/164/ZP_Files/ pirls-literacy-2016_grade-4_15-dec-2017_low-quality.zp137684.pdf.

Howie, S., Van Staden, S., Tshele, M., Dowse, C. \& Zimmerman, L., 2012, Progress in international reading literacy studies 2011: South African children reading literacy achievement (summary report), Centre for Evaluation and Assessment, Pretoria. 
Howie, S., Venter, E., Van Staden, S., Zimmerman, L., Long, C., Du Toit, C. et al., 2008, Progress in international reading literacy studies 2006: South African children Progress in international reading literacy studies 2006: South African children
reading literacy achievement (Summary report), Centre for Evaluation and reading literacy achievement (Summary

Ibukunolu, A.A., 2013, 'Parenting style and students' academic achievement in junior secondary schools in Ogun State, Nigeria', Journal of Emerging Trends in Education Research and Policy Studies 5(1), 20-24.

Jeynes, W., 2007, 'The relationship between parental involvement and Urban secondary school students academic achievement', Urban Education 42(1) 82-110. https://doi.org/10.1177/0042085906293818

Jeynes, W., 2012, 'Meta-analysis of the efficacy of different types of parental involvement programs for urban students',. Urban Education 47(4), 706-742. https://doi.org/10.1177/0042085912445643

Kern, R., 2014, 'Technology as pharmakon: The promise and perils of the internet for foreign language education', The Modern Language Journal 98(1), 340-357. https://doi.org/10.1111/j.1540-4781.2014.12065.x

Lau, H.Y.E., Li, H. \& Rao, N., 2011, 'Exploring parental involvement in early years education in China: Development and validation of the Chinese early parental involvement scale (CEPIS)', International Journal of Early Years Education 20(4), 405-421. https://doi.org/10.1080/09669760.2012.743099

Liu, X., 2013, 'Home literacy environment' influence on language and reading development' Unpublished master's thesis, University of Michigan, Ann Arbor, MI.

Maguire, M. \& Delahunt, B., 2017, 'Doing a thematic analysis: A practical, step-by-step guide for learning and teaching scholars', Journal of Teaching and Learning in Higher Education 3, 3351-3354.

Mbokodi, S.M. \& Singh, P., 2011, 'Parental partnerships in the governance of schools in the Black townships of Port Elizabeth', Perspectives in Education 29(4), 38-48.

McCabe, R., 2011, 'An academic literacy course: Making choices', Journal for Language Teaching 45(2), 47-67. https://doi.org/10.4314/jlt.v45i2.3

Mji, A. \& Makgato, M., 2006, 'Factors associated with high school learners' performance: A spotlight on mathematics and physical science', South African Journal of Education 26(2), 253-266.

Mmotlane, R., Winnaar, L. \& Wa Kivilu, M., 2009, 'Personal characteristics that predic South Africans' participation in activities of their children's schools', South African Journal of Education 29, 527-540. https://doi.org/10.15700/saje.v29n4a294

Mncube, V., 2009, 'The perceptions of parents of their role in the democratic governance of schools in South Africa: Are they on board?', South African Journal of Education 29, 83-103. https://doi.org/10.1590/S0256-01002009000100006

Mncube, V., Harber, C. \& Du Plessis, P., 2011, 'Effective school governing bodies: Parental involvement', Acta Academia 43(3), 210-242.

Munje, P.N. \& Maarman, R., 2017, 'Do school resources matter? The effects of school resources on learner performance in poor school communities', Journal of Educational Studies 16(1), 34-51.

Nel, N., 2011, 'Second language difficulties in a South African context', in E. Landsberg, D. Kruger \& E. Swart (eds.), Addressing barriers to learning: A South African perspective, pp. 167-185, Van Schaik, Pretoria.

Nieuwenhuis, J., 2007, 'Qualitative research designs and data gathering techniques', in K. Maree (ed., Revised Version), First step in research, pp. 98-122, Van Schaik, Pretoria.

O'Donoghue, K.L., 2014, 'Barriers to parental involvement in Schools: Developing diverse programs to include unique demographics', Education and Human Development Master's thesis, Brockport College, New York.

Okeke, C.I., 2014, 'Effective home-school partnership: Some strategies to help strengthen involvement', South African Journal of Education 34(3), 1-9. https:// doi.org/10.15700/201409161044

Page, R.D., 2016, 'The role that parents play in their children's academic progress at a previously disadvantaged primary school in Cape Town', Unpublished Master's thesis, University of Western Cape, Western Cape.

Patten, M.L. \& Newhart, M., 2018, Understanding research methods: An overview of the essentials, Routledge, New York.
Phillips, C. 2011, Child-headed households: A feasible way forward, or an infringement of children's rights to alternative care, viewed 05 May 2013, from www. charlottePhillips.org.

Prinsloo, C.H., 2008, The plus-time project: Extra classes, extra marks, Human Science Research Council, Pretoria, viewed 20 August 2018, from http://www.hsrc.ac.za/ en/research-outputs/view/3625.

Prinsloo, C.H., Rogers, S.C. \& Harvey, J.C., 2018, 'The impact of language factors on learner achievement in Science', South African Journal of Education 38(1), 1-4. https://doi.org/10.15700/saje.v38n1a1438

Ramrathan, L., 2017, 'Learner poor performance: Provoking Bourdieu's key concepts in analysing school education in South Africa', Southern African Review of Education 23(1), 23-36.

Slain, L., 2019, Challenges of parental involvement in education, Human and Hope Association, viewed 04 August 2018, from https://www.humanandhopeassociation. org/challenges-parental-involvement-education/.

South African Schools Acts, No 84 of 1996, 1996, Government Gazette 1998, President's office, Pretoria.

Southern and Eastern African Consortium for Monitoring Educational Quality (SACMEQ), 2011, Trends in achievement levels of Grade 6 pupils in South Africa, Policy Brief, number 1, SACMEQ, 05 May 2013, from www.sacmeq.org.

Statistics South Africa, 2011, Census 2011: Census in brief, Statistics South Africa. Pretoria

Statistics South Africa, 2018, General household survey, South African Statistics. Pretoria

Stein, N., 2017, Basic education rights handbook, Chapter 11, South Africa, Pretoria. Section 27, viewed 12 September 2018, from http://section27.org.za/wp-content/ uploads/2017/02/Chapter-11.pdf.

Stewart, D.W. \& Shamdasani, P.N., 2015, Focus groups: Theory and practice, Sage, Los Angeles, CA.

Stott, D., 2015, 'Using fluency activities in after school maths clubs to enhance learner performance in the primary grades', Journal of Educational Studies: Special Issue on Breaking Barriers Hindering Learner 181-202.

Symington, S. \& Dunn-Coetzee, M., 2015, 'A psycho-educational strategy as toll for educating adolescents on internet safety', The Social Work Practitioner-Researcher 27(3), 306-321. https://doi.org/10.25159/2415-5829/721

Teddlie, C. \& Tashakkori, A., 2009, Foundations of mixed methods research: Integrating quantitative and qualitative approaches in the social and behavioural sciences, Sage, London.

Tekin, A.K., 2011, 'Parental involvement revisited: Background, theories, and models', International Journal of Engineering and Applied Sciences 11(1), 1-13.

Vaismoradi, M., Jones, J., Turunen, H. \& Snelgrove, S., 2016, 'Theme development in qualitative and content analysis and thematic analysis', Journal of Nursing Education and Practice 6(5), 100-110. https://doi.org/10.5430/jnep.v6n5p100

Wang, H., 2014, 'Home literacy environment, the quality of mother-child book reading interactions, and Taiwanese children's early literacy development', Unpublished Doctoral Dissertation, Syracuse University, Syracuse, NY.

Wei, J., 2014, 'Selectivity of second language attrition', Theory and Practice in Language Studies 4(8), 1603-1608.

Wei, R., 2011, 'Parental support for Chinese-English bilingual education: A survey of parents of primary and secondary students in Shanghai', Journal of Multilingual and Multicultural Development 32(5), 481-496. https://doi.org/10.1080/014346 32.2011 .592588

Wessels, S., 2014, 'Supporting English and Spanish literacy through a family literacy program', School Community Journal 24(2), 67-82.

Willemse, T.M., Thompson, I., Vanderlinde, R. \& Mutton, T., 2018, 'Family-school partnerships: A challenge for teacher education', Journal of Education for Teaching: International Research and Pedagogy 44(4), 1-6. https://doi.org/10.10 80/02607476.2018.1465545

Wium, A.M. \& Louw, B., 2018, 'Mixed-methods research: A tutorial for speechlanguage therapists and audiologists in South Africa', South African Journal of Communication Disorders 65(1), 1-3. https://doi.org/10.4102/sajcd.v65i1.573 